\title{
Method of biological treatment of agricultural waste by microbial synthesis
}

\author{
Galia Kokieva ${ }^{1, *}$, Aleksandr Pekhutov $^{2}$, Sergey Petunov ${ }^{2}$, Marfa Okhlopkova ${ }^{3}$, and \\ Nadezhda Kondakova ${ }^{1}$ \\ ${ }^{1}$ Arctic State Agrotechnological University, 3, Sergelyakhskoe shosse the 3 km, 677007, Yakutsk, \\ Russia \\ ${ }^{2}$ The Buryat State Agricultural Academy of V.R.Filippova, 8, Pushkin Str., 670024, Ulan-Ude, Russia \\ ${ }^{3}$ Northeastern Federal University named after MK Ammosov, 58, Belinsky Str., 677007, Yakutsk, \\ Russia
}

\begin{abstract}
Traditional manure management is unacceptable for dilute manure, the share of which in the structure of organic waste from livestock farms and complexes is continually increasing. The approach is relevant, at the first stage of implementation, it is necessary to create the supply base for non-conventional energy using, including organic biomass energy (manure, crop waste, etc.). Also, the problem of waste utilization is closely linked to another - environment protection, which requires intensive recycling of animal agriculture. It requires necessary to search reclamation methods that would ensure the utilization of agrotechnical, energetic, feed, and other properties. The article presents the treatment process of manure utilization by microbial synthesis.
\end{abstract}

\section{Introduction}

The problem of waste utilization is closely linked to another - environment protection, which requires intensive recycling of animal agriculture. Indicators determining that characterize the effectiveness of anaerobic technologies is challenging because there are few biopower plants where it would be possible to perform experiments for obtaining objective data.

Research and development of liquid manure utilization have led to the emerging science-complex biotransformation of farm animal waste to energy and produce feed protein. Accumulated at our institute, the experimental material, and practical experience allowed us to create biphasic process and equipment samples for manure recycling. Analysis of manure physical properties after fermentation has shown that dry ash-free substance decomposition was $22 \%$ with a daily loading dose of $4.5 \%$. The manure moisture and its ash content increase after fermentation, which is explained by the partial expenditure of dry matter for biogas.

Based on experimental data on the output of biogas and decomposition of manure, the most effective doses of average daily loading of the methane tank were determined. It is established that the maximum value of this indicator should not exceed 4.5 and $9 \%$ in

\footnotetext{
*Corresponding author: kokievagalia@mail.ru
} 
mesophilic and thermophilic modes, respectively. When the loading dose is increased, the output of biogas decreases, and the process is unstable. Thus, in laboratory conditions, it was possible to reduce the exposure of methane fermentation to 3 days and ensure the yield of protein from $1 \mathrm{~m} 3$ of biogas to $300 \mathrm{~g}$ (ACV) at a biomass density of $25 \mathrm{~g} / 1$.

To develop and implement environmentally friendly and resource-saving technologies for the intra-soil pre-sowing and sowing application of mineral fertilizers and a set of new generation machines complex for their implementation in intensive farming.

In recent years, interest in biogas production processes has grown significantly this is manifested not only in the growing number of planned and under construction biogas plants, but also in the interest of an increasing number of farmers, utilities, enterprises, politicians and private farms, which are closely monitored the development of this sector. The study of physical and microbiological indicators of manure, and their dependence on the modes and processing methods allowed to analyze the known technological schemes and equipment for methane fermentation of organic waste and getting feed additives from it [3 p.2, 7 p.95]. The aim of the work is to review the equipment of microbial synthesis.

\section{Research methods}

In agriculture, the basis of biogas plant production is crop waste utilization and manure from livestock farms. It is estimated that $1 \mathrm{~kg}$ of solid waste (chaff, sawdust) produces about $0.25 \mathrm{~m} 3$ of biogas and $0.6 \mathrm{~kg}$ of compost [1,2], $1 \mathrm{~kg}$ of poultry manure can produce biogas with a volumetric heat value of over $21 \mathrm{MJ} / \mathrm{m} 3$. Sludge remaining after fermentation as feed additives or organic fertilizers [3]. American experts believe that the power potential of the livestock manure daily volume in the United States is equivalent to 51 million liters of gasoline. Biogas volumetric heat value is on average $\mathrm{MJ} / \mathrm{M} 3$, which matches the heat obtained by combustion of 0.6 liters of liquid fuel.

Biogas, comprising $63 \ldots 68 \%$ of methane and $32 \ldots 37 \%$ of carbon dioxide deliquesce at a pressure of $0.1 \mathrm{MPa}$ and a temperature $-161.5^{\circ} \mathrm{C}$. In this form, it takes up the minimum volume, which is essential when using for technical objectives. The tank farm with a capacity of $32 \mathrm{~m} 2$ can accommodate liquefied gas; its energy content is equivalent to 29.5 thousand $\mathrm{m} 3$ of biogas in the normal state or 17.7 thousand tons of diesel fuel. It is estimated that the annual demand for biogas for heating a domestic building is about $45 \mathrm{~m} 3$ per $1 \mathrm{~m} 2$ of living space, the daily consumption for water heating-up for 100 heads of bovine is $5 \ldots 6 \mathrm{~m} 3$. The biogas consumption when drying 1 ton of grain is $15 \mathrm{~m} 3$, and to get $1 \mathrm{~kW} * \mathrm{~h}$ of electricity, it is needed $0.7 \ldots 0.8 \mathrm{~m} 3$. Biogas plants produce, besides electricity, hot water for heating or other process needs. Installation engines can run on a mixture of 15 ... 20\% liquid fuel and $85 \ldots 80 \%$ methane.

The difficulty of using biogas for a truck is placing gas bottles because their volume should be about 5 times greater than the volume of the truck with diesel fuel. It is deemed convenient to install biogas cylinders on a truck (40 liters each): four to place for two on each side, and the fifth-under the driver's seat. The amount of biogas provides the truck operation at full load for 3.5 hours or 7 hours at a $40 \%$ load. Because of the high antiknock property of biogas, it can serve as an excellent fuel for gas-engine with forced ignition, and diesel, without requiring additional re-equipment (it makes only power system adjustments). To improve heat removal from the atomizer body, it presses copper sleeves at their ends. In comparative tests, the specific consumption of diesel was $220 \mathrm{~g} / \mathrm{kWh}$ at rated power, and of biogas- $0.4 \mathrm{~m} 3 /(\mathrm{kWh})$, while it was required about $30 \mathrm{~g} /(\mathrm{kWh})$ of "starting" fuel (diesel used as a " lighter" for biogas). As a result, the diesel economy was $86 \%$. At $40 \%$ engine load and rate speed of crankshaft 1400 min-1 (the average loading level of trucks in Switzerland), diesel consumption is $250 \mathrm{~g} /(\mathrm{kWh})$, when using biogas-80 $\mathrm{g} /(\mathrm{kWh})$ plus gas consumption of $0.6 \mathrm{~m} 3 /(\mathrm{kWh})$, which corresponds to almost $70 \%$ diesel 
savings. Anaerobic methane fermentation of manure allows us to get biogas, it is a valuable organic fertilizer with enhanced bioactivity, or protein-vitamin concentrate for feed supplementation $[2,4]$. Such manure recycling is an effective environmental action that ensures deodorization, reducing soil and water pollution with different substances and pathogenic microflora, injection into the atmosphere (for the displacement of traditional organic fuel by biogas).

In world practice, there is much experience in creating biogas plants [3]. There are existing installations in our country; some of them are under construction.

Because of the analysis of the existing biogas plants economic characteristics, it was determined that their specific indicators (the cost of $1 \mathrm{~m} 3$ of reactor volume, $1 \mathrm{t}$ of biogas) are not the same, and they are many times higher than such indicators for typical installations used in urban wastewater treatment systems. The reason for this is that it builds biogas plants as pioneers, the cost of research work is attributed to them, foreign design organizations are attracted, and so on. It builds most of the biogas plants with steel reactors. The standard ones developed for wastewater treatment systems include reinforced concrete ones. Reactors are the most expensive part of a biogas plant. The annual cost of it comprises capital investment and operating costs to compensate for heat loss to maintain the required temperature of the biomass $\left(35^{\circ} \mathrm{C}\right.$ for mesophilic and $55{ }^{\circ} \mathrm{C}$ for thermophilic modes). The most common schemes of installations in which the necessary thermal regime is provided by using part of the biogas produced in them. Over 30\% of the total gas is consumed for heating biomass [4]; in a plant planned as a series, the share of gas used for its own needs is $50 \%$ [5]. In some works $[9,10]$ it sets this indicator between $30 \ldots 70 \%$. Here it is proposed to reduce the cost of gas for heating biomass by switching the installation in the cold months to the mode of manure accumulation without issuing gas.

Because of this, manure impedes the normal and safe functioning of livestock farms located directly in localities. The lack of technologies for processing manure leads to longterm accumulation of manure near farms near natural reservoirs, which leads to their heavy pollution. Thus, for the ingress of biogenic elements into lakes, the content of nitrates, nitrites, ammonium, and phosphates exceeds the permissible norms. In some lakes of the Zarechnaya districts group of the Republic of Sakha (Yakutia), the excess of the MPC of nitrates by $110-120$ times, and phosphates by $70-80$ times was noted. In rural areas, the population consumes water from these reservoirs with no treatment. This leaves no doubt that manure is a critical factor in the infectious transmission and invasive diseases to humans and animals, an infection source of pastures and reservoirs. The issues of intensification of protein biosynthesis processes from biogas in relation to low-tonnage agricultural installations that implement biosynthesis processes at normal atmospheric pressure also need serious scientific and theoretical study and generalization. Solving these problems will first significantly improve the performance of equipment without increasing the volume of the reactor, limited by the possibility of its transportation, and also move to the development of high-performance large volume bioreactors [1,6]. Here, it is possible to ensure the effective use of biogas plants on livestock farms and complexes, preserving the block-modular principle of equipment building sets.

\section{Main Part}

Figure 2 shows a diagram of the anaerobic digester 


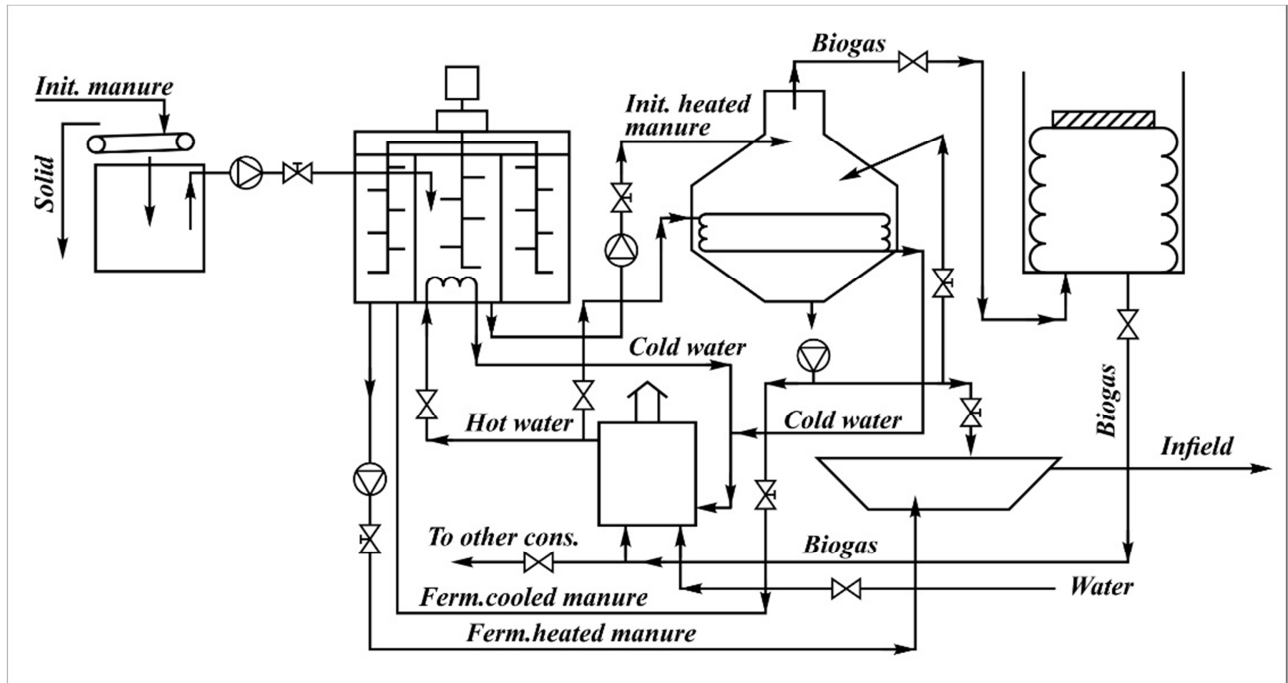

Fig. 1. Scheme of a bioenergy installation.

Anaerobic techniques of processing cattle manure require necessary adaptation for costeffective implementation in Yakutia because of technical and processing demerits. One of the main factors of microbiological process flow in anaerobic digesters is the residence time of microorganisms in the medium (retention time). To effectively decomposition fecal organic matter to $\mathrm{CH} 4$ and $\mathrm{CO} 2$, it is necessary to have a fair number of microorganisms in the support medium, provide the required residence time in the medium to achieve substrate metabolism and eliminate bacterial flushing.

\subsection{Results and discussion}

Table 1 shows the data of cultivation in the equipment

Table 1. The data of cultivation in the equipment.

\begin{tabular}{|c|c|c|c|c|c|c|c|}
\hline \multirow[b]{2}{*}{ № } & \multirow{2}{*}{$\begin{array}{l}\text { Cul- } \\
\text { ture } \\
\text { time }\end{array}$} & \multicolumn{2}{|c|}{$\mu_{\text {Max }}$} & \multicolumn{2}{|c|}{$\begin{array}{l}\text { Indieators } \\
\text { Biomass accumulation. } \\
\text { bln/ml }\end{array}$} & \multirow{2}{*}{$\begin{array}{c}\text { Geniture } \\
\text { minimal } \\
\text { time } \\
\text { g }_{\text {min.hour }}\end{array}$} & \multirow{2}{*}{$\begin{array}{c}\text { The } \\
\text { amount of } \\
\text { glucose } \\
\text { during the } \\
\text { cultivation. } \\
\text { ml }\end{array}$} \\
\hline & & $\begin{array}{l}\text { Optical } \\
\text { density }\end{array}$ & $\begin{array}{c}\text { Total } \\
\text { viable cells }\end{array}$ & $\begin{array}{l}\text { Optical } \\
\text { density }\end{array}$ & $\begin{array}{c}\text { Total } \\
\text { viable } \\
\text { cells }\end{array}$ & & \\
\hline \multicolumn{8}{|c|}{ Instructive condition } \\
\hline 1 & 14 & $1.3 \pm 0.01$ & $0.9 \pm 0.004$ & $5.4 \pm 0.15$ & $4.8 \pm 0.01$ & $0.6 \pm 0.1$ & 35.4 \\
\hline 2 & 12 & $1.1 \pm 0.07$ & $0.98 \pm 0.05$ & $6.7 \pm 0.2$ & $5.9 \pm 0.21$ & $0.71 \pm 0.01$ & 36.2 \\
\hline \multicolumn{8}{|c|}{ Experimental condition } \\
\hline 3 & 14 & $1.14 \pm 0.03$ & $0.77 \pm 0.33$ & $15.4 \pm 0.4$ & $14.2 \pm 0.35$ & $1.0 \pm 0.01$ & 330.20 \\
\hline 4 & 12 & $0.1 \pm 0.02$ & $0.92 \pm 0.02$ & $20.4 \pm 0.45$ & $15.4 \pm 0.4$ & $0.82 \pm 0.01$ & 280.14 \\
\hline 5 & 9 & $0.47 \pm 0.02$ & $0.01 \pm 0.001$ & $8.4 \pm 0.3$ & $4.0 \pm 0.02$ & $0.9 \pm 0.01$ & 129.18 \\
\hline 6 & 10 & $0.711 \pm 0.03$ & $0.62 \pm 0.02$ & $12.9 \pm 0.04$ & $5.0 \pm 0.1$ & $1.62 \pm 0.02$ & 150.00 \\
\hline
\end{tabular}

When studying the process of oxygen absorption in a nutrient medium of different viscosities, for gas-oil ratio calculation is used: 


$$
\frac{\varphi}{(1-\varphi)^{4}}=0,2\left(\frac{D^{2} * \rho_{f} * \mathrm{~g}}{\sigma}\right)^{0,62} *\left(\frac{D^{3} * \rho_{f}{ }^{2} * \mathrm{~g}}{\mu_{f}}\right)^{\frac{1}{12}} * \frac{W_{\mathrm{r}}}{(D * \mathrm{~g})^{0,5}}
$$

where $D$ is the device diameter.

To calculate $W j$, we recommend it to use the Bernoulli equation, recused for the circulation circuit of the following form:

$$
H\left(p_{f}-p_{r}\right) \varphi * g=\Delta P_{b}+\Delta P_{c}
$$

At the moment, during the feed protein production, when the cultivation of microorganisms in the culture liquid, several reactions occur in the fermentation liquid with oxygen. For liquid reactions with oxygen which received wide distribution in the industry, for calculating $W_{f}$ is recommended:

$$
\mathrm{H}\left(\rho_{f}-\rho_{r}\right)^{*} \mathrm{~g}=\left[\left(1.5+\lambda_{c} \frac{H}{d_{c}}\right)\left(\frac{f_{b}}{f_{c}}\right)^{2}+2+\frac{1}{(1-\varphi)^{2}}+\frac{\lambda_{b} * H}{(1-\varphi)^{1.75} * d_{6}}\right] * \frac{\rho_{f} W_{f}^{2}}{2} .
$$

This calculation is performed by the selected equations suitable for determining the gas content in the culture medium. At a pressure of up to $4 \mathrm{MPa}$ on a medium with properties similar to the "water-air" system, and the ratio of bubbling and circulation zones $f b^{*} f \mathrm{c}$ $1=1$, which is close to the value of the reduced fluid velocity, the same authors propose to calculate $W_{f}$ using a simplified equation:

$$
W_{f}=3,5\left[\frac{H * \beta}{\xi k} *\left(\frac{\Delta \rho}{\rho_{r}}\right)^{0,125}\right]^{0,5}
$$

where $\xi_{\mathrm{k}}=5,1+0,03\left(\frac{H}{d_{b}}+\frac{H}{d_{c}}\right)-$ resistance coefficient of the circulation circuit.

On the gas surface, they form the liquid of the air bubble into air films. They pass through the culture, making it difficult for oxygen to diffuse through the fermenter volume and reduce the resulting resistance. 7].

Several works are devoted to the study of oxygen absorption processes in fermenters [1-

When considering this case with poorly soluble gas (oxygen), the values of $m_{p c}$ и $K_{r}$ are large, and the diffusion resistance in the gaseous phase can be ignored, and we observe the inequality:

$$
\begin{aligned}
\frac{1}{K_{L} a} \gg \frac{1}{K_{r} m_{p c}}, \\
k \approx k_{l a}
\end{aligned}
$$

Based on the equality $k \approx k_{l a}$ the mass transfer equation: $\frac{d c}{d y}=k_{i} * a\left(c_{p}-c\right)-k_{b} * \mathrm{x}$,

Left equation term $\frac{d^{2} M}{d V_{p} d t}=k\left(c_{p}-c\right)$, called the rate of oxygen volumetric mass transfer or dissolution rate of oxygen, for the atmospheric absorption oxygen by the culture liquid is written as follows:

$$
\frac{d^{2} M}{d V_{p} d t}=K_{L} a\left(c_{p}-c\right)
$$

The stability and efficiency of the methods allow further modification of the calculation technology, including the selection of turbulence models, to improve the accuracy of calculations. 
The operation of biogas plants provides an economic effect (cheap fuel) for an additional one. The latter is primarily understood as an increase in the organic fertilizer value got after fermentation. Plant nutrition elements $\mathrm{K} 2 \mathrm{O}$ and P $2 \mathrm{O} 5$ in the fermentation remain unchanged in quantity and as compounds in which we find them. The initial amount of nitrogen does not change, but it passes to other compounds. If nitrogen is mainly included in organic compounds of liquid manure, then in the sediment (sludge), it is found mainly in ammonia. The transformation intensity of organic nitrogen forms into ammonia depends on the duration of the fermentation process. Plants more quickly absorb ammonia forms than organic ones. This increases the efficiency of sludge application in grain crops. When fertilizing with manure, green lands sludge, and perennial grasses, the difference in efficiency is somewhat reduced, although when using sludge on perennial pastures, the growth of grasses is noticeably accelerated. With the conversion of organic nitrogen forms to ammonia, the sludge physical properties significantly improve-it becomes less viscous, it is easier to homogenize and pump, and it flows faster from plants when sprayed, which reduces the possibility of burn (at high $\mathrm{pH}$ values). During fermentation, it also destroys eggs and larvae of parasites.

\section{Conclusion}

Thus, methane fermentation of manure in combination with the processing of the biogas released in this process into feed protein based on controlled microbial synthesis- a new production process that provides both energy and feed additives. This technology makes it possible to implement a sped up cycle of bioconversion of substances at a livestock enterprise parallel to the traditional path of their regeneration in crop production, which provides real opportunities for creating livestock complexes in the form of waste-free production, satisfying all the economy and environmental protection. Analysis of the physical properties of manure after fermentation showed that decomposition of dry ashless substance was $22 \%$ with a daily loading dose of $4.5 \%$. Humidity of manure and its ash content after fermentation increase, for the partial expenditure of dry matter on the formation of biogas.

Based on experimental data on biogas yield and decomposition of manure, the most effective doses of the average daily loading of the on-site sewage facility were determined. We established it that the maximum value of this indicator should not exceed 4.5 and $9 \%$ in the mesophilic and thermophilic modes, respectively. With an increase in the loading dose, the biogas yield decreases, and the process could be is unstable.

\section{References}

1. V.P. Druzyanova, Scientific support for the implementation of the national project in agriculture: materials of scientific-practical conference of teachers, employees and graduate students, 58-60 (2010)

2. V.P. Druzyanova, All-Russian scientific youth. school-conference-Omsk, 230-231 (2010)

3. G.E. Kokieva, Scientific and Technical Bulletin of the Volga Region, 123-125 (2014)

4. G.E. Kokieva, Scientific and Technical Bulletin of the Volga Region, 137-139 (2014)

5. G.E. Kokieva, Bulletin of the Buryat State Agricultural Academy named after V.R. Filippova, 95-100 (2016) 
6. S. Rudov, V. Shapiro, I. Grigorev, O. Kunitskaya, V. Druzyanova, G. Kokieva, A. Filatov, M. Sleptsova, A. Bondarenko, D. Radnaed, International Journal of Civil Engineering and Technology 10(1), 2052-2071 (2019)

7. S.E. Rudov, A.M. Voronova, J.M. Chemshikova, E.V. Teterevleva, I.N Kruchinin, Yu.Zh. Dondokov, M.N. Khaldeeva, I.A. Burtseva, V.V. Danilov, I.V. Grigorev, Asian Journal of Water, Environment and Pollution 16(4), 61-75 (2019)

8. Yu.A. Shaposhnikov, V.P. Druzyanova, G.E. Kokieva, K.R. Nifontov, M.N. Sidorov, Periodico Tche Quimica 15(S1), 67-76 (2018)

9. Y.A. Shaposhnikov, A.V. Tyunin, 2nd International Conference on Industrial Engineering, Applications and Manufacturing, ICIEAM 2016 - Proceedings, 7911632 (2016)

10. Yu.A. Ivanov, V.I. Pakhomov, S.I. Kambulov, D.V. Rudoi, ICMTMTE 2018 MATEC Web of Conferences 224, 05023 https://doi.org/10.1051/matecconf/201822405023 